\title{
The Role of Social Capital in the Development of Mauhalek Waterfall Ecotourism in Belu District, East Nusa Tenggara Province
}

\author{
Nopriyan Petrus Klau ${ }^{1 *}$, Aminudin $\mathrm{Affandi}^{2}$, Iwan Nugroho ${ }^{3}$ \\ ${ }^{1}$ Master Program of Environmental Sciences, Postgraduate School, University of Brawijaya, Malang, Indonesia \\ 2Postgraduate School of Enviromental Sciences, University of Brawijaya, Malang, Indonesia \\ ${ }^{3}$ Department of Agribusiness, Faculty of Agriculture, Widyagama University of Malang, Malang, Indonesia
}

\begin{abstract}
The purpose of this research is to know the relationship and the role of social capital in supporting product and service of Mauhalek waterfall ecotourism. Phenomenology approach was chosen because it allow the researcher to identify a particular phenomenon, and requires the researcher to examine the subject by being directly involved in developing meaningful patterns and relationships. In the context of the research to be studied, the main focus of this research is the norms, beliefs, networks, products, and services of Mauhalek waterfall. From the research results, it can be concluded that there are various custom rules in maintaining Mauhalek waterfall which still exists until now, one of them is ukum Badu (prohibition of cutting the tree and taking fruit that existing around the Mauhalek forest). The high belief in myths and rules makes the sustainability of Mauhalek waterfall is still maintained until now. The beauty and authenticity of natural resources and culture of Mauhalek waterfall make it as a good tourist product to be offered to the visitor.
\end{abstract}

Keywords: Mauhalek waterfall, social capital, sustainable tourism.

\section{INTRODUCTION}

In Nusa Tenggara Timur region, tourism destination is growing rapidly in line with the development of technology and communication in the region. Tourism is one of the important industrial sectors and has great potential and opportunity to be developed [1]. Some of the existing tourism offers are very diverse, ranging from marine tourism, mountain, agro, animal etc. [2]. Precisely in Belu Regency, in the city which directly adjacent to the Democratic Republic of Timor Leste (RDTL), there is a very interesting diversity of tourism such as Mauhalek waterfall tourism located in Lasiolat Sub-district, Raiulun Village. The concept of tourism development offered at Mauhalek waterfall is the existing tourism development harmonized with environmental conservation issues and the empowerment of local community related to the culture and customs of the local community [3].

The interesting charm in a tourism destination is an attraction, either in the form of art shows, recreation, or presentation of a typical packed and preserved local culture [4]. The aspects in the development of ecotourism model consisted of social, natural, human, physical, and economic aspect. The implementation of

\footnotetext{
${ }^{*}$ Correspondence address:

Nopriyan Petrus Klau

Email : nopriyan.klau@yahoo.com

Address : Postgraduate School, University of Brawijaya, MT Haryono No. 169, Malang 65145.
}

ecotourism is basically done with simplicity, maintaining the integrity of nature and the environment, maintaining the authenticity of customs, living habits or the way of life [1].

The social capital is a feature of social organization such as network, norms and social trust that can facilitate the coordination and cooperation for mutual benefit. Thus, the main attribute of social capital consists of the norm, trust, and networking [5]. The term ecotourism can be interpreted as a trip by a tourist to a remote area with the aim of enjoying and learning about nature, history, and culture in an area where the tourism pattern helps the economy of the local community and supports nature conservation [6].

This research about the community's social capital in improving tourism development which is conducted at Mepar Village, Lingga Subdistrict, Lingga Regency. In this research, the writer finds the value of Mepar people that is still developing until now. This informal value is an effort to encourage the formation of tourist event such as Safar bath, haul jama' and malam tujuh liko at the village. The value that encourages the tourist events as mentioned above is known to the community by tolak bale which means it refuses from ill-fated or dangerous and also invites lucky fate or known to the local community with the word Mojo [7]. The social capital is then developed until now because of the success of society in conserving it. 
Social Capital that owned by the head of the family to develop the marine ecotourism itself, is considered quite well. This is related to their income and education level. However, when correlated with the social capital, it is more influential on the level of understanding of norms and the number of people who are known on the social network they had. However, there's insufficient or fading belief of the community; especially in the ecotourism development [8].

Social capital in tourism development can be seen in the research conducted in Basring Village. The social capital contained in the Group of Nelayan Ikan Hias Samudera Bakti has the positive influence in the success of the empowerment program conducted to fishermen of Bangsring Village. They are changing the fishing pattern from the environment unfriendly to be environmentally friendly and able to invite the fishermen to maintain and preserve the existing marine environment. The existing social capital in the Group of Nelayan Ikan Hias Samudera Bakti is social capital that tends to be inward-looking, usually the type of bonding social capital tends to be conservative and prioritizes group solidarity rather than more tangible things to build itself and the group in accordance with the guidance of values and norms of more open society [2].

Ecotourism cannot be separated from social capital [9]. One of the indicators of social capital is local wisdom, where the local wisdom of people around the Mauhalek waterfall has relevance to the development of Mauhalek waterfall. The purpose of this research is to study the role of social capital in supporting product and service of Mauhalek waterfall ecotourism.

\section{RESEARCH METHODS}

\section{Phenomenology Approach}

This study used a phenomenology approach. Phenomenology was chosen because the researcher able to identify a particular phenomenon, and it requires the researcher to examine the subject by being directly involved in developing meaningful patterns and relationships [10]. In the context of the research to be studied, the main focus of this research is the norms, beliefs, networks, products, and services of Mauhalek waterfall.

\section{Data Collection}

Qualitative data obtained from the selected people by purposive sampling, namely the technique of determining the sample with a certain consideration. In Raiulun Village, four respondents were chosen because they were considered to understand the existing development and the existing potentials in the research area. The research population is the Village Head of Raiulun, Mauhalek waterfall management, the customary stakeholder of Raiulun Village, and community. The respondents was determined by snowball sampling approach, namely the technique of determining sample initially small in number, then increasing because the information obtained is not complete yet.

The collected data are (1) social, economic and environmental conditions in the research area, (2) factors in social capital (norm, trust, and network) that exist in the research area, and (3) product and services available at the research area. Judging from the type of data, there are two types of data collected in this study, namely primary data and secondary data. The main data used to compile the model in this study are primary data collected through questionnaires to the respondents who are interested people in the research location. While the secondary data from village's document and Mauhalek waterfall management. The data collected is about (1) social, economic and environmental conditions at the research location, (2) the state of social capital of the Raiulun Village community based on norms, beliefs and networks, and (3) products and services from Mauhalek waterfall.

\section{RESULT AND DISCUSSION Regional Overview}

This research conducted in Dualasi Raiulun Village, Lasiolat Sub-district, Belu District, East Nusa Tenggara Province. Raiulun Village has 9 $\mathrm{km}^{2}$ of Village area which is surrounded by hills, with altitude of $924 \mathrm{~m}$ asl (above sea level). Climatologically, Raiuliun Village is at an average temperature of $24-34^{\circ} \mathrm{C}$ tropical climate, the geographical position closer to Australia than Asia, making Raiulun Village has low rainfall between 1000-1500 mm.year ${ }^{-1}$. The topography of Raiulun village varies between altitude 0 and $+1500 \mathrm{~m}$ asl.

Raiulun Village has 875 people with 440 men (50.5\%) and 445 women (49.5\%) and 223 households [11]. The social life of customs society of Raiulun Village is divided into several tribes. It can be seen in table 1 that there are 11 tribes at this Raiulun Village. These tribes have the tribal chief who will regulate and run the customary rules of their lives. 
Table 1. Community Tribes of Raiulun Village

\begin{tabular}{clcl}
\hline No & Tribe Name & No & \multicolumn{1}{c}{ Tribe Name } \\
\hline 1 & Dua besi & 7 & Mone sogo \\
2 & Reuba & 8 & Mone hitu \\
3 & Bere gatal & 9 & Mone walu \\
4 & Lakus & 10 & Hakpor \\
5 & Tuli gatal & 11 & Leoes \\
6 & Sirigatal & & \\
\hline \multicolumn{2}{l}{ Source: } & Custom Stakeholder of Raiulun village (2017)
\end{tabular}

Community work at Raiulun Village is quite diverse. Starting from the farmer, civil servant, the vegetable seller, maker of woven cloth (typical of Belu Regency), taxi bike driver, and cattleman, but most of them are farmers. This is supported by the fertile condition of agricultural land. The types of farms grown are rice paddy, maize, tubers, and vegetables. Within a year, agricultural production can produce 3,399 - 7,585 tons per year.

Raiulun villagers also have livestock in each house. The large livestock population is 799 animals, the small livestock population is 453 animals, and the poultry livestock population are 2,131 . Other than that, the community around Mauhalek waterfall has the small industry, i.e. weaving industry; with 60 weaving industries has been registered [11]. Raiulun Village is one of the villages in Lasiolat Sub-district with low economic level and the average income level of the community is IDR 250,000 and for the highest income is IDR 4,000,000. This revenue is derived from the sale of agricultural products, plantation, livestock, woven fabric, and salary that works as the civil servant or contract worker.

\section{Social Capital of Community around Mauhalek Waterfall}

There are three social capital indicators that will be described in the management of waterfall Mauhalek, namely norm, belief, and network. Generally, the various rules and local wisdom in preserving nature is a factor that relates to norms, trust between Raiulun people and trust of Raiulun people to the government or other party; wich is one of the indicators of social capital, namely trust. Furthermore, the meeting intensity between Raiulun people and acceptance of information and relation between people or from outside the community is the network. Here is an explanation of the social capital variable through each indicator of the variable.

\section{Norm}

The behavior of social capital of the community is directly described by the norms, values, and rules prevailing in that society [12].
Here are the rules for the management of Mauhalek waterfall based on the local wisdom of Raiulun Village. Table 2 explained the rules or norms that exist at Mauhalek waterfall.

\begin{tabular}{|c|c|c|c|}
\hline Finding & Meaning & Description & Sanction \\
\hline $\begin{array}{l}\text { Ukum } \\
\text { Badu }\end{array}$ & $\begin{array}{l}\text { Not damage } \\
\text { the waterfall } \\
\text { and forest } \\
\text { that exist } \\
\text { around the } \\
\text { waterfall }\end{array}$ & $\begin{array}{l}\text { Already } \\
\text { destroying the } \\
\text { natural } \\
\text { surrounding } \\
\text { that guarded } \\
\text { by their } \\
\text { ancestor }\end{array}$ & $\begin{array}{l}\text { Animal, sopi, } \\
\text { sirih pinang } \\
\text { (paan), cloth }\end{array}$ \\
\hline $\begin{array}{l}\text { Halikutar } \\
\text { hasa oan }\end{array}$ & $\begin{array}{l}\text { Traditional } \\
\text { ritual } \\
\text { mentioning } \\
\text { the Lord and } \\
\text { the Land and } \\
\text { the ancestor } \\
\text { and landlord } \\
\text { who find the } \\
\text { waterfall }\end{array}$ & $\begin{array}{l}\text { Getting grace } \\
\text { from the } \\
\text { water called } \\
\text { the supreme }\end{array}$ & - \\
\hline $\begin{array}{l}\text { Mata } \\
\text { merek }\end{array}$ & $\begin{array}{l}\text { People who } \\
\text { see or find a } \\
\text { person or } \\
\text { group of } \\
\text { people who } \\
\text { damage the } \\
\text { waterfall }\end{array}$ & $\begin{array}{l}\text { Witness in the } \\
\text { process of } \\
\text { customary law } \\
\text { as a person } \\
\text { who sees and } \\
\text { finds the } \\
\text { incident }\end{array}$ & $\begin{array}{l}\text { Getting part } \\
\text { in } \\
\text { sanctioning } \\
\text { of the } \\
\text { perpetrator }\end{array}$ \\
\hline Foho & $\begin{array}{l}\text { Mesba or } \\
\text { compound } \\
\text { stone }\end{array}$ & $\begin{array}{l}\text { Used as a } \\
\text { place of } \\
\text { offerings to } \\
\text { the ancestor in } \\
\text { the traditional } \\
\text { ritual }\end{array}$ & - \\
\hline Tarahorak & $\begin{array}{l}\text { Apologizing } \\
\text { to the } \\
\text { ancestor }\end{array}$ & $\begin{array}{l}\text { Apologizing to } \\
\text { the ancestor } \\
\text { for damaging } \\
\text { Mauhalek } \\
\text { waterfall }\end{array}$ & $\begin{array}{l}\text { Bringing } \\
\text { sanctions } \\
\text { that } \\
\text { determined } \\
\text { by the tribal } \\
\text { chief }\end{array}$ \\
\hline
\end{tabular}

The customs people at Raiulun Village has a rule where people are not allowed to deforest the existing forest at Mauhalek waterfall area. The forest around the waterfall should be preserved because custom people of Raiulun Village believe that the waterfall and its surroundings are the inheritance of their ancestors who have been used or utilized from the past until now for their survival. Furthermore, the waterfall and its surrounding such as forest around the waterfall should not be cut because they believe that every tree has a guard. According to the residents, if they are found to be cut, it will be given a custom sanction in the form of fines such as animal (pig), sirih pinang (paan), and sopi (traditional drink).

The animal used as fines is in accordance with the size or the number of trees cut which is determined by the custom stakeholder of 
Raiulun Village in the custom language called ukum Badu. Raiulun Village community cooperate in adhering to the customary law at Mauhalek waterfall, this is evidenced by the presence of matan merek which means People who see or find a person or a group of people who damage Mauhalek waterfall then the person will report to the head of the tribe or commonly called tua adat. After that, it will be followed by tua adat will give sanction to someone or group of people who damage this Mauhalek waterfall. The excellence of this matan merek is he/she will get a special part from the result of sanction given to a person who damages this waterfall.

At Mauhalek waterfall, there is a levelled stone used as mesba or place in doing custom procession called foho. This place is usually used by tribes belonging to Bunak tribe that is one of the four major tribes. There are 11 tribes in Belu Regency -the small tribe of Bunak tribe which uses the levelled stone as mesba which is believed to be a means of bringing them closer to their ancestors and as a source of harmony for the people around the waterfall, the tribes believe it as halikutar hasa oan. In addition, it is also used in the apology ceremony to the ancestors resulting from the destruction of Mauhalek waterfall by bringing sanction determined by tua adat called tarahorak.

\section{Trust}

The relationship between Raiulun villagers in accordance with the results of the interviews that they have excellent relations between people. It can be seen from the form of high trust in fellow villagers in Raiulun also manifested in the implementation of traditional activities. Customary activities that are held always involve all parties and do not distinguish the Raiulun Village community based on their class or social stratification. The existence of mutual trust between communities encourages the sustainability of social relations that support in a community order. A form of high trust to Raiulun villagers is also realized in the implementation of ceremonial activity such as ceremony of halikutar hasa oan (ceremony performed as thanksgiving to the God and to the ancestors). The ceremonial activity is usually done once in a year during the harvest season in September. The ceremonial activity always involves all parties and does not distinguish Raiulun villagers based on social group or stratification.

Raiulun villagers also believe that violating the rules that have been created and mutually agreed upon will cause disaster for the tribe or community group such as crop failure and drought as well as danger to the individual or someone's life such as the person will get ill and also get the misfortune such as accident etc.

\section{Network}

The relation of Raiulun villagers with the government is very good. The government of Raiulun Village is very supportive of the activity undertaken by Raiulun villagers, i.e. tourism management activity of Mauhalek waterfall. In addition, this activity is supported by opening the road for the tourist attraction of Mauhalek waterfall by using village funds and assistance from relevant departments such as department of public works and department of tourism as promotion media of tourist attraction for Mauhalek waterfall.

The trust of Raiulun villagers towards the government is shown in the form of appreciation of every monitoring from the related agency, serving and reporting every result of Mauhalek waterfall management. This activity is often done at the village office or invited to the activities made by the related agency. These activities are conducted with the intention of monitoring and evaluation and determining tourism destination management strategy that exists in Belu Regency including Mauhalek waterfall.

The establishment of BUMDes Raiulun (Village-owned Business Agency) is based on the potential of Raiulun Village which has Mauhalek waterfall and this formation is intended for economic improvement of Raiulun villagers. Early formation of this BUMDes in 2016 formed by the Village Head of Raiulun. Membership in BUMDes is taken from people who have willingness in accordance with the purpose of BUMDes establishment, i.e. the management of Mauhalek waterfall [3].

\section{Ecotourism of Mauhalek Waterfall}

Mauhalek waterfall area has a high diversity of flora and fauna because Mauhalek waterfall tourism is initially the customary forest that preserved various existing ecosystems. Mauhalek waterfall forest has 14 species of trees namely Pinang (areca nut), mahogany, avocado, tamarind, jackfruit, mango, lamtoro, teak, candlenut, palm, white teak, sandalwood, Guava (Syzygium), and Eucalyptus. Fauna in waterfall Mauhalek are monitor lizards, monkey, eagle, sparrow, wild pig etc. This condition is huge potential as an ecotourism attraction (Table 3). Landscape at Mauhalek waterfall is the 
combination of various physical components of the ecosystem with surrounding vegetation creating a very beautiful panorama as part and object and tourist attraction, the landscape has significant role and position in a tourism destination. In Figure 1 can be seen the beauty of Mauhalek waterfall.

Table 3. Product and Service of Mauhalek Waterfall Source: Field Observation (2017)

\begin{tabular}{|c|c|c|}
\hline No & Product And Service & Explanation \\
\hline 1 & $\begin{array}{l}\text { Landscape and } \\
\text { environmental and } \\
\text { cultural attraction }\end{array}$ & $\begin{array}{l}\text { Flora and fauna, springs, } \\
\text { waterfall, bunak culture, } \\
\text { typical food of local } \\
\text { community }\end{array}$ \\
\hline 2 & Landscape benefit & $\begin{array}{l}\text { Tracking to waterfall, } \\
\text { waterfall bath, } \\
\text { photography, shopping the } \\
\text { result of local community } \\
\text { garden }\end{array}$ \\
\hline 3 & $\begin{array}{l}\text { Accommodation } \\
\text { and facility of } \\
\text { support services }\end{array}$ & $\begin{array}{l}\text { Stall, cottage, bathroom, } \\
\text { toilet and dressing room, } \\
\text { traditional market }\end{array}$ \\
\hline 4 & $\begin{array}{l}\text { Equipment and } \\
\text { supply }\end{array}$ & Tour guide, motorcycle taxi \\
\hline 5 & Education and skills & $\begin{array}{l}\text { Research of local wisdom } \\
\text { and woven fabric }\end{array}$ \\
\hline 6 & $\begin{array}{l}\text { Awards, } \\
\text { conservation } \\
\text { accomplishment or } \\
\text { service }\end{array}$ & Not formally \\
\hline
\end{tabular}

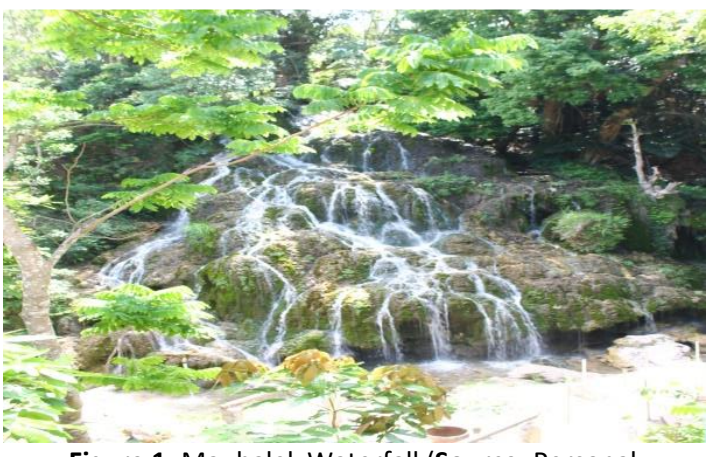

Figure 1. Mauhalek Waterfall (Source: Personal Documentation, 2017)

Cultural tourism that can be seen is the existence of traditional worshiping ceremony, namely worshiping the ancestors which are often held in this waterfall by 11 tribes. It is believed that the stones are composed of this waterfall is mesba or place of worship to the ancestors. Observation in the field shows that this area can be used as a tourist attraction because it is one of the first waterfall attractions and it can be used to rest and relax with the cool air. There are many trees and a beautiful waterfall that make the visitor very comfortable to be in this Mauhalek waterfall area.
The advantage of the Raiulun villagers is that they trust their customary leader (head of tribe). In addition, the Raiulun villagers religiously obey the regulations issued by their customary leader. The reason is that Mauhalek waterfall is a protected water source from ancient by their ancestors before it is designated as a tourism area. They assume that the waterfall and the two sources of water are life source, so they keep this Mauhalek waterfall for the preservation of nature and the source of its water are still maintained until now. They keep this waterfall with a variety of custom rules, one of them is badu ukum (prohibition of cutting down trees and taking fruit around the Mauhalek forest). High belief in myths and rules passed by the customary leader (head of tribe) that makes the community of Raiulun village still preserve this Mauhalek waterfall.

The role of community social capital of Raiulun Village in developing products and services of Mauhalek waterfall tourism is very good. It can be seen from several norms that have existed since antiquity which makes this waterfall tourism maintain the authenticity and beauty of Mauhalek waterfall. It also supported by the compliance of the community of Raiulun Village in complying with existing rules, and also the level of trust among people is also very high due to the familial relations of the tribes at Raiulun Village, the village community is very obedient to the tribal chief (tua adat), village head and other village officers. The relation of mutual trust which makes Raiulun villagers can establish cooperation in the management of this waterfall goes well.

With the existence of Mauhalek waterfall tourism, the Raiulun villagers have more awareness to preserve the environment with written rules made in PERDES (Village Rules). The assistance of planting tree seeds to enrich existing resources, with the help and socialization of the community, make they understand more about the importance of maintaining the environment theoretically.

From the results of this study in accordance with the theory of Putnam [4], stated that social capital is a feature of social organizations such as networks, social norms and beliefs that can facilitate coordination and cooperation for mutual benefits. These three aspects have their respective roles and facilitate each other to get mutual benefits. In the aspect of norms having a role in preserving the natural resources of the waterfall of Mauhalek with customary rules and 
sanctions that apply in the Raiulun Village community. The norm can also serve as a reminder of the type or tourism activities that can be done and cannot be done. This certainty is considered absolute because it has been decided jointly and contains strong traditional elements.

\section{CONCLUSION}

Norm or rule that exists at Raiulun Village is very strong because all of the villagers highly uphold the local wisdom they have. They strongly believe by continuing to preserve the local wisdom, then their life will be safe and serene. They keep this waterfall with various custom rules, one of them is badu ukum (prohibition of cutting trees and taking fruit that exists around the Mauhalek forest). Customary community trust of Raiulun Village has been planted since their ancestors and also the Raiulun villagers believe what is said by the customary leader (head of tribe). It is seen from obedience to the orders and rules issued by their customary leader (head of tribe), Raiulun Villagers network has been formed through the organization of BUMDes established by village head of Raiulun in 2016 with the intention as a place for the surrounding community to manage the Mauhalek waterfall.

The role of community social capital of Raiulun Village in developing product and service of Mauhalek waterfall tourism are very good seen from some norms that have existed. Antiquity makes this waterfall tourism is maintained the authenticity and beauty, which also supported by the obedience of Raiulun villagers in compliance with ukum Badu (traditional rules) that has been there, and with the willingness to develop the Mauhalek waterfall, Raiulun villagers who joined in the group of BUMDes develop and add the Mauhalek waterfall facility with the income they get and support from the government of Belu District as an intention to increase the comfort of tourists.

\section{Acknowledgement}

The writer conveys many thanks to the parties who have provided assistance, both moral and material, namely Ferdinan Manek as Village Head of Raiulun, A.tallo as the customary stakeholder of Raiulun village, H.Y.Mau as chairman of BUMDes Raiulun, and Y.loe as the community of Raiulun Village which has provided information related to this research.

\section{REFERENCES}

[1] Parmawati, R., Y. Saktiawan, F. A. A. Wibowo, A. S. Kurnianto. 2018. Analysis of village tourism development in Sawahan, Trenggalek Regency, Indonesia: A sustainable livelihood approach. E-Journal of Tourism 5(1), 46-53.

[2] Kusuma, U. A., D. Satria, A. Manzilati. 2017. Modal sosial dan ekowisata: studi kasus di Bangsring Underwater, Kabupaten Banyuwangi. Jurnal IImu ekonomi dan Pembangunan, 17(2), 1-30.

[3] Belu Regency. Medium Term Development Plan (RPJM) of Belu Regency 2016 - 2021. Belu Regency.

[4] Department of Culture and Tourism. 2009. Panduan pemasaran pariwisata yang bertanggungjawab (Responsible Tourism Marketing). Department of Culture and Tourism. Jakarta.

[5] Putnam. R. 1993. The prosperous community: social capital and public life. The American Prospect 13, 65-78.

[6] Department of Culture and Tourism. 2009. Prinsip dan kriteria ekowisata berbasis masyarakat. Department of Culture and Tourism and WWF-Indonesia. Jakarta.

[7] Kurniawati. 2015. Modal sosial masyarakat dalam peningkatan pembangunan pariwisata. Jurnal Ilmu-Ilmu Sosial 2015, 27-42.

[8] Azhari. 2013. Modal sosial masyarakat dalam mengembangkan ekowisata bahari di Pulau Pramuka Dki Jakarta. Available at: http://repository.ipb.ac.id/jspui/bitstream/ 123456789/66322/1/I13yaz.pdf

[9] Baksh, R. 2013. Deskripsi modal sosial masyarakat di Desa Ekowisata Tambaksari (studi kasus Desa Tambaksari, Kecamatan Purwodadi, Kabupaten Pasuruan, JawaTimur). Jurnal Agroland 19(3), 193-199.

[10] Creswell, J. W. 2010. Research design: pendekatan kualitatif, kuantitatif, dan mixed. PT. Pustaka Pelajar. Yogyakarta.

[11] Statistic Center Beureau of Belu District. 2017. Lasiolat Sub-district in numbers. Statistic Center Beureau of Belu District.

[12] Liu, H., W. Ke, K. K. Wei and Y. Lu. 2014. The effects of social capital on firm substantial and symbolic performance in the context of E-business. PACIS 2014 Proceeding. 328. 